\title{
SLCO1B3 wt Allele
}

National Cancer Institute

\section{Source}

National Cancer Institute. SLCO1B3 wt Allele. NCI Thesaurus. Code C106618.

Human SLCO1B3 wild-type allele is located in the vicinity of 12p12 and is approximately $279 \mathrm{~kb}$ in length. This allele, which encodes solute carrier organic anion transporter family member 1B3 protein, is involved in both bile acid and bilirubin transport and sodiumindependent uptake of endogenous and xenobiotic compounds. Mutations in this gene are associated with hyperbilirubinemia, Rotor type, digenic. 